\title{
Managing high-density tailings disposal - deposition, water management and closure considerations
}

\author{
S Kam Golder Associates Ltd., Canada \\ D Yaschyshyn Glencore Canada Corp., Canada \\ N Hmidi Goldcorp Canada Corp., Canada
}

\begin{abstract}
There has been a growing interest in the surface disposal of high-density tailings in recent years. Such an interest is driven primarily by the need to conduct mining in a sustainable manner by minimising environmental and social impact, conserving water and improving tailings safety. Increasingly, more mines are considering thickened or paste tailings disposal in conjunction with paste tailings backfill to better utilise their infrastructure.
\end{abstract}

Several factors have hindered the wider adoption of high-density surface tailings disposal technology. The ability to predict tailings behaviour in full scale is still relatively limited. There is also little experience in managing a high-density tailings facility under varied climatic conditions. A number of high capacity mines have also had production issues meeting the tailings consistency criterion for deposition leading to major reconfiguration of the disposal system due to poor field performance. Some of these uncertainties are being addressed through laboratory and field research with significant advances being made on our understanding on tailings rheology, transportation, mechanism of deposition and post deposition behaviour change of the tailings.

High-density tailings facilities will require a greater degree of management than conventional slurry tailings. Not only are the tailings likely more variable, there are unique challenges associated with tailings deposition and water management. This paper discusses tailings deposition control and water management methods that have been successfully used at a number of high-density tailings facilities with special reference made to central cone deposition in the Kidd Metallurgical Site and perimeter deposition at the Musselwhite Mine. Both of these facilities are located in cold climatic regions in Canada with surplus precipitation. Contingency measures that have been adopted to reduce the risk of system upsets and non-performance, and closure considerations for these facilities are highlighted. Field experience has shown that high-density tailings disposal can offer unique opportunities for progressive rehabilitation and optimisation of the closure design.

\section{Introduction}

In operation since 1973, the Kidd Metallurgical Site (Metsite) is the world's first production-scale thickened tailings disposal facility. Despite the long history at this site, the application of high-density tailings technologies to surface disposal only began to receive attention in the late 1990s and 2000s when advances were made in utilising paste tailings as mine backfill. Many of the early high-density tailings facilities were located in Australia, where the climate is more conducive to tailings drying and stacking. In many cases, the key drivers for high-density tailings disposal were low dam construction cost and water conservation. With increasing public awareness tailings management practices now must demonstrate their compliance with the principle of environmental and social sustainability and that the tailings dams are safe. The growing trend of high-density tailings disposal is a result of these changes.

Benefits of high-density tailings as compared to conventional slurry tailings disposal can range from smaller footprint, lower water consumption, better protection against acid rock drainage and metals leaching, 
lower dam failure risk, greater flexibility in site reclamation, to better dusting control. While these benefits are relatively well known and demonstrated in some tailings applications, progress towards adopting high-density tailings disposal is still slow due to a number of obstacles including high costs, lack of field experience especially in specific geographic and climatic settings and uncertainty in predicting the tailings beach slope. Recent experiences have also highlighted the difficulty in scaling up this technology to a large production facility, both from equipment and from tailings disposal perspectives. Tailings operation can be complex when surface disposal is conducted in conjunction with mine backfill or cycloning to produce material for construction.

This paper discusses deposition, water management and closure issues for several common high-density tailings disposal methods with special reference to an environment of net surplus precipitation and subzero temperatures. Experience gained at the Kidd Metsite and the Musselwhite Mine is presented. For the purpose of discussions below, high-density tailings refer to thickened or paste tailings but not mechanically filtered tailings.

\section{Types of disposal}

There are four general methods of high-density tailings disposal according to the level of control and location of discharge point. Table 1 provides details of some existing tailings for each category.

Central discharge (CD) - In a CD facility the tailings are discharged from the interior, often in the centre of the tailings management area (TMA). Deposition will result in tailings mounding up to form a cone around the discharge point. Surface runoff and excess process water if any are collected at the perimeter. As the bulk of the tailings are in the interior, the perimeter dams can be relatively low. In many CD facilities, the perimeter dams are periodically raised to increase the storage capacity. The $\mathrm{CD}$ can be unregulated as in the case of vertical discharge towers. More often, the slurry flow is controlled by discharging from a central access road or with a 'wagon wheel' arrangement (Cooper \& Smith 2011). The ability to control directional flow of tailings is important as discussed further in Section 3. When tailings are discharged along a line in the centre of the TMA, a ridge will form. In a hybrid configuration, the tailings line can be moved onto the beach to form individual cones of tailings.

Perimeter discharge (PD) - A PD facility is developed by discharging tailings slurry along one or more sides of the TMA, with the resulting tailings beach sloping towards the interior. Tailings deposition can be adjusted along the perimeter dams to achieve the desired configuration. Additional tailings capacity is created by raising the perimeter dams. Upstream stacking on the tailings beach is a technique commonly used in area of low seismicity.

Cell deposition (CDP) - Relatively small tailings cells are constructed and filled sequentially in this type of facility. Not only does cell construction allow the tailings to be placed in a specific area, it also provides good control on the amount of tailings to be placed. The completed cells can be rehabilitated during the operating period. Often cells are operated intermittently to allow the deposited tailings to undergo a specific degree of drying. With a smaller surface area, cell deposition can be less susceptible to dusting. CDP requires the most construction effort on a unit tailings volume basis.

Down-valley discharge (DVD) - In this type of facility, the tailings slurry is discharged from elevated ground into a valley that is closed by a dam. The tailings pond will be maintained against an engineered dam. The resulting tailings beach is largely a function of the topography. 
Table 1 High-density tailings disposal methods and select example facilities

\begin{tabular}{|c|c|c|c|c|c|c|c|c|}
\hline $\begin{array}{l}\text { Tailings } \\
\text { deposition } \\
\text { method }\end{array}$ & Variation & Facility & Climate & $\begin{array}{l}\text { Tailings } \\
\text { consistency } \\
\text { \% solids }\end{array}$ & $\begin{array}{l}\text { Discharge } \\
\text { rate }\end{array}$ & $\begin{array}{l}\text { Dam raise } \\
\text { method }\end{array}$ & $\begin{array}{l}\text { Max. } \\
\text { beach } \\
\text { length }\end{array}$ & Reference \\
\hline \multirow[t]{3}{*}{$\begin{array}{c}\text { Central } \\
\text { discharge }(C D)\end{array}$} & $\begin{array}{l}\text { Single or multiple } \\
\text { towers }\end{array}$ & Bulyanhulu & Arid & Paste, 74\% & $2,000 \mathrm{tpd}$ & $\begin{array}{l}\text { Perimeter } \\
\text { stacking }\end{array}$ & $285 \mathrm{~m}$ & Theron et al. (2005) \\
\hline & $\begin{array}{l}\text { With directional } \\
\text { control }\end{array}$ & Kidd Metsite & Wet, cold & $\begin{array}{c}\text { Thickened, } \\
61 \%\end{array}$ & 5,500 tpd & $\begin{array}{l}\text { Internal berm } \\
\text { stacking }\end{array}$ & $1,200 \mathrm{~m}$ & Kam et al. (2009) \\
\hline & & Sunrise Dam & Arid & $\begin{array}{c}\text { Thickened, } \\
60 \%\end{array}$ & 10,000 tpd & $\begin{array}{l}\text { Perimeter } \\
\text { stacking }\end{array}$ & $850 m$ & $\begin{array}{c}\text { Fitton (2014); } \\
\text { Williams et al. (2008) }\end{array}$ \\
\hline \multirow[t]{2}{*}{$\begin{array}{c}\text { Perimeter } \\
\text { discharge (PD) }\end{array}$} & $\begin{array}{l}\text { From perimeter } \\
\text { dams }\end{array}$ & Nunavik & Permafrost & $\begin{array}{l}\text { Thickened, } \\
60 \% \text {, in lined } \\
\text { basin }\end{array}$ & 4,500 tpd & $\begin{array}{l}\text { Downstream } \\
\text { raising }\end{array}$ & $600 \mathrm{~m}$ & $\begin{array}{l}\text { Habte et al. (2014), } \\
\text { K Habte (pers. comm., } \\
\text { October 2014) }\end{array}$ \\
\hline & From tailings stack & Musselwhite & Wet, cold & $\begin{array}{c}\text { Thickened, } \\
68 \%\end{array}$ & 4,000 tpd & $\begin{array}{l}\text { Perimeter } \\
\text { stacking }\end{array}$ & $1,000 \mathrm{~m}$ & Kam et al. (2014) \\
\hline \multirow[t]{2}{*}{$\begin{array}{l}\text { Cell deposition } \\
\text { (CDP) }\end{array}$} & $\begin{array}{l}\text { Over subaqeously } \\
\text { deposited tailings, } \\
\text { central deposition }\end{array}$ & Neves Corvo & Semi-arid & $\begin{array}{c}\text { Thickened, } \\
59-69 \%\end{array}$ & $\begin{array}{c}4,100- \\
6,800 \text { tpd }\end{array}$ & Dyke raise & $120-200 \mathrm{~m}$ & $\begin{array}{l}\text { Lopes et al. (2013); } \\
\text { Raposo et al. (2014) }\end{array}$ \\
\hline & $\begin{array}{l}\text { Dedicated cells for } \\
\text { strength gain }\end{array}$ & $\begin{array}{l}\text { Various, oil } \\
\text { sands }\end{array}$ & Wet, cold & & Field trials & & & Yuan \& Lahaie (2010) \\
\hline $\begin{array}{l}\text { Down-valley } \\
\text { discharge } \\
\text { (DVD) }\end{array}$ & & Century & Arid & $\begin{array}{c}\text { Thickened, } \\
54 \%\end{array}$ & 13,000 tpd & $N / A$ & $2,500 \mathrm{~m}$ & $\begin{array}{c}\text { Fitton (2014); } \\
\text { Williams et al. (2008) }\end{array}$ \\
\hline
\end{tabular}




\subsection{Example facilities}

\subsubsection{Kidd Metallurgical Site}

The Kidd Metsite TMA in Timmins, Ontario is the world's first large scale thickened tailings disposal facility The CD TMA contains about $132 \mathrm{Mt}$ of copper/zinc tailings as of end of 2013 and has a surface area of $1250 \mathrm{ha}$. The site is located in a region characterised by surplus precipitation and sub-zero temperatures in winter.

Figure 1 shows an aerial view of the TMA in 2014. The TMA has a 600 ha active tailings deposition area. The thickened tailings slurry is discharged from pipes placed from the access roads, resulting in the formation of a cone extending over a distance of $1.2 \mathrm{~km}$ from the apex. The centre of the cone is $30 \mathrm{~m}$ higher than the perimeter dyke. Until 2002, the perimeter dyke contained the tailings and served to divert the runoff to Ponds A and C. Since then, over $7 \mathrm{~km}$ of internal berms have been built upstream of the dyke to retain tailings; these berms are periodically raised using the upstream construction method.

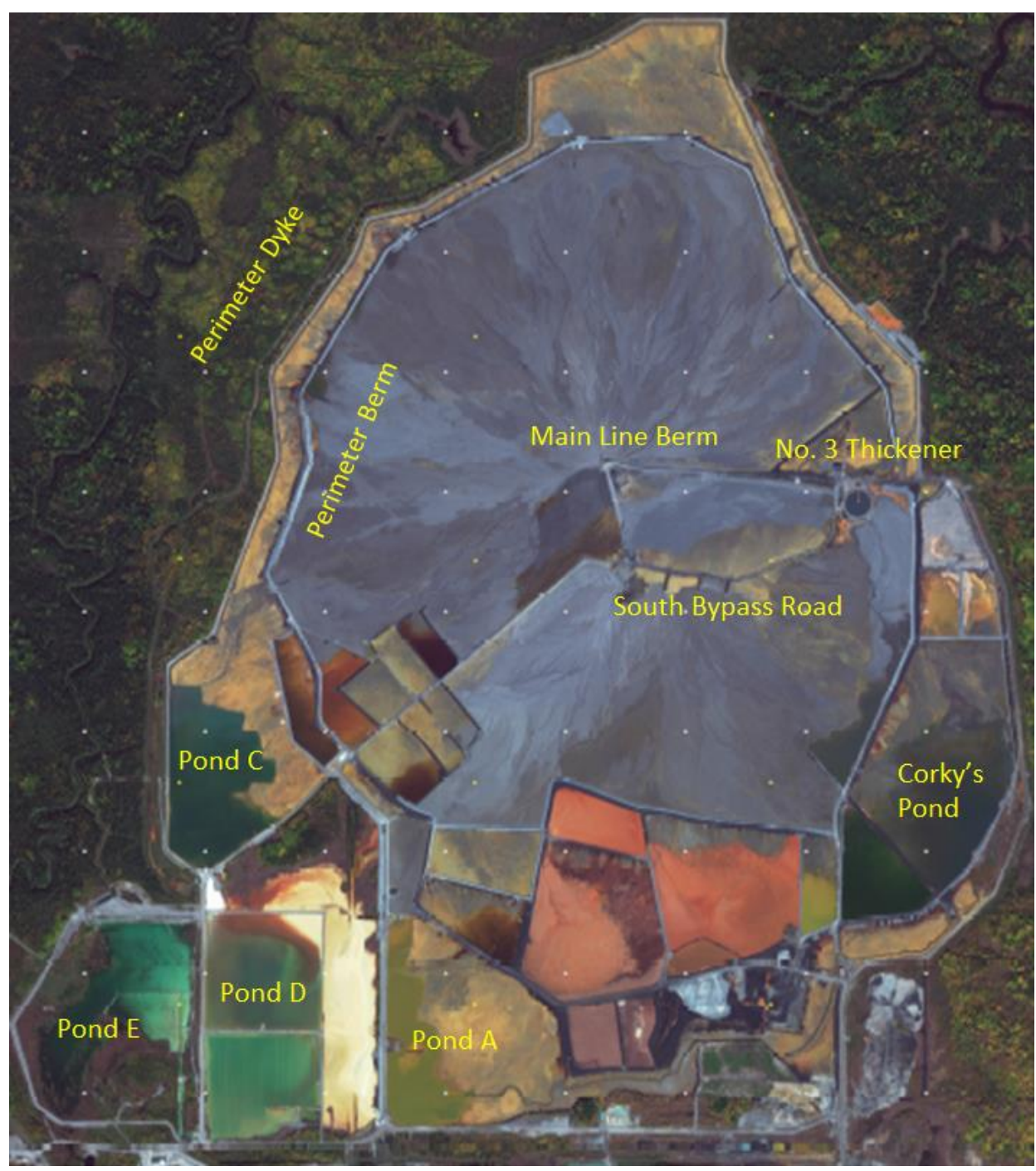

\section{Figure 1 Kidd Metsite tailings management area (2014)}

The tailings slurry is thickened in the No. 3 Thickener to a solids content of 60-65\%. Thickener underflow and seepage waters are treated with lime at the outlets of Ponds $A$ and $C$ and discharged to Settling Pond D. On average, $33,000 \mathrm{~m}^{3}$ of treated effluent are discharged to the Porcupine River each day. Pond D is dredged typically twice a year and the sludge is disposed of in several cells. Special holding cells have also 
been constructed to store the tailings that are periodically dredged from ponds. Refer to Kam et al. (2009) for a more detailed description of the Kidd TMA operations.

\subsubsection{Musse/white Mine}

Musselwhite Mine is located in north-western Ontario, Canada, where subzero temperatures prevail from November to April. Average annual precipitation is $733 \mathrm{~mm}$ compared to $410 \mathrm{~mm}$ of lake evaporation.

Gold mining began at Musselwhite in 1997. The tailings are stored in a 133 ha TMA located $3 \mathrm{~km}$ west of the process plant. The tailings contain up to $1.5 \%$ sulphur and are acid-generating. An aerial view of the TMA is shown in Figure 2. Tailings containment is provided by a series of low-permeability, zoned earthfill perimeter dams. The TMA was originally designed for $13.7 \mathrm{Mt}$ of tailings with a shallow water cover for closure. The TMA capacity was later expanded by converting to thickened tailings disposal and tailings stacking from the perimeter. Since 2010, a total of $6.5 \mathrm{Mt}$ of thickened tailings have been placed from the west end of the TMA over four stages of dyke raise (Kam et al. 2014). The PD TMA design will provide total storage for $32 \mathrm{Mt}$ of tailings. A dry cover will be provided for closure.

The TMA consists of a west cell for tailings deposition and an east cell for managing water, separated by a rockfill internal dyke. Thickened tailings are discharged primarily from the west with the tailings stack raised to a maximum height of 18 metres in the upstream direction.

The Musselwhite Mill processes about 4,000 tonnes per day (tpd). The thickened tailings slurry has a density of $68 \%$ weight solids and is end discharged from the discharge dyke. The thickener overflow drains to the tailings pond, where water is reclaimed by a pump barge. Excess water in the tailings pond is pumped to the polishing pond and released to the environment from May to November each year. Annually, Musselwhite discharges just over $2 \mathrm{M} \mathrm{m}^{3}$ of water.

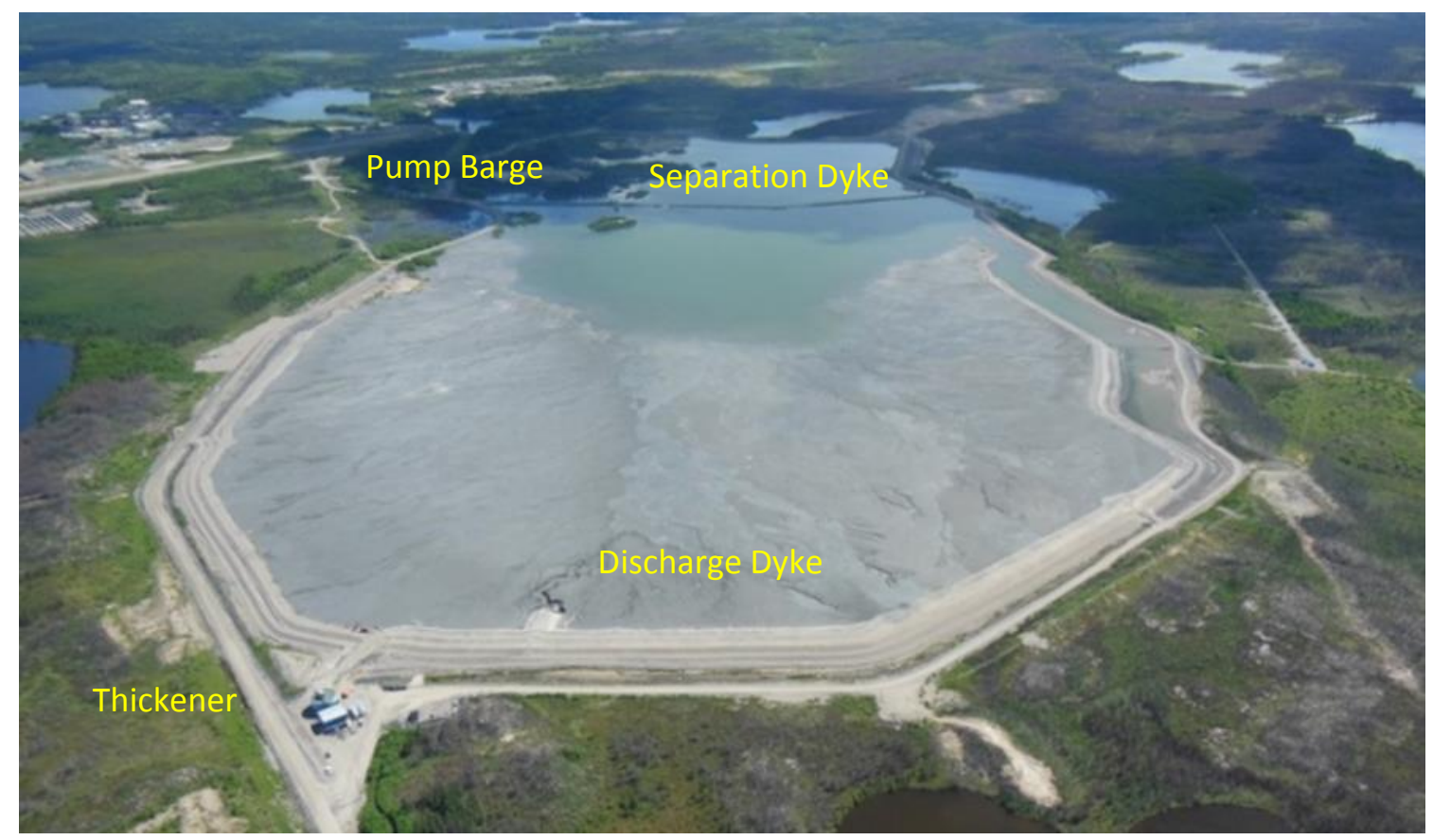

\section{Figure 22013 aerial view of Musselwhite TMA}

\subsubsection{Neves Corvo Mine}

Neves Corvo Mine is located $220 \mathrm{~km}$ south of Lisbon, Portugal. The local climate is semi-arid, with average annual precipitation of $484 \mathrm{~mm}$ and evaporation of about 1,313 $\mathrm{mm}$ per year.

The underground copper/zinc mine was commissioned in 1988. The tailings are acid generating and had been deposited subaqueously until 2010 when sub-aerial deposition of thickened tailings in cells began (Lopes et al. 2013). The current deposition strategy is to store the life of mine tailings using sub-aerial 
deposition of thickened tailings in cells. The test work demonstrated that with a high water retention capability thickened tailings can significantly slow the tailings oxidation rates.

The sub-aerial deposition design entails depositing thickened tailings sequentially into 15 cells, each with approximately six months to one year capacity. The cells are separated by mine waste rock dykes. In each cell, tailings are deposited from one or more spigots. Deposition alternates between these cells and spigots every few days to allow the thin lifts of tailings to be exposed for up to one and a half months (Raposo et al. 2014). The sequential cell filling and placement of final cover allows for progressive site restoration and better control of acid generation and runoff.

\section{$3 \quad$ Tailings deposition}

\subsection{Factors affecting field performance}

The desirable characteristics of high-density tailings deposition are site-specific but can include a steep beach slope (minimise perimeter dam construction), good post-deposition strength gain (facilitate access and construction), high in situ density (reduce storage requirement), high water retention capability (inhibit oxygen ingress, reduce seepage), no particle sorting (reduce pond size), and resistant to surface and wind erosion (minimise dusting). Tailings field performance will depend on the following factors:

- Tailings properties - The settling behaviour of tailings is strongly affected by the tailings rheology, which is function of the tailings material and the thickening and transportation processes. Various studies have attributed poor field performance to a lack of control on the tailings feed and inadequate plant operation (Wates et al. 2014; Lopes et al. 2013). While it is desirable to avoid variability of characteristics of the tailings feed, this is very difficult to achieve when the coarse tailings are used to backfill the mine (which is a batch process). Other factors that can affect plant performance can include interruption of the mill feed, equipment failures, power outages and change in the mineralogy of the ore.

- Climate - Dewatering of the deposited tailings on tailings beach is critically important to achieve good gains in strength The primary mechanism to remove water from the settled tailings is evaporation. This process is enhanced by surface cracking which exposes the underlying material and provides a new flow path for water to evaporate. In cold climate, freezing/thaw cycles also contribute to tailings dewatering through formation of ice lenses which melt when the ground is thawed (Caldwell et al. 2014). Thin lift deposition and maximising the wetted surface promote evaporation from tailings.

- Deposition controls - The mode of tailings discharge, the location and the duration of deposition can directly affect tailings beach formation. Discharging tailings slurry from multiple spigots is generally preferred over end of pipe discharge because of a lower potential for tailings erosion and a more uniform beach profile due to sheet flow. Spigotting, however, is not always feasible in freezing environment because of a high potential for clogging.

- Rate of deposition - The rate at which the tailings beach is built up is an important consideration when planning deposition. A rapid rate of deposition can lead to low strength gain from consolidation and atmospheric drying. High porewater pressure could be generated within the tailings mass reducing the overall stability of the perimeter dams.

\subsection{Observation-based deposition approach}

The current state of knowledge does not allow accurate prediction of the deposition behaviour of tailings as the tailings settling and transportation processes on a beach are complex. Fitton (2014) compared a number of published beach slope prediction models and found that for the cases investigated these models showed considerable scattering in the result. It is the authors' opinion that the disagreement with the observed conditions may be attributed to several reasons, including quality of data that was fed into these 
models, limitation of the model assumptions, and operational/climatic variability that cannot be accounted for.

Given the many operational and climatic factors that can affect tailings beach formation, tailings deposition operation should best be managed with an observational approach. This is particularly important where beach length is long and the topography is variable. In a CD facility, the tailings slurry can spread considerably as it travels down the beach. An uneven build-up of tailings at the perimeter of the cone can interfere with the drainage and present difficulty to dam construction. For this type of facility the deposition location and duration of discharge should be adjusted based on field observation along the TMA perimeter. In comparison, PD provides a greater degree of control on the rate of tailings build-up and on the beach profile as the discharge point(s) can be moved readily along the dam crest. The cost of dam construction for PD, however, is generally higher. As the beach slopes to the interior of the TMA and no water is impounded against the perimeter dam, the discharge line may be extended onto the tailings beach to achieve additional storage capacity, if necessary.

\subsection{Case studies}

\subsubsection{Central discharge}

Until 2002, the perimeter dyke retained the tailings discharged from the centre of the Kidd TMA. With the available storage capacity substantially depleted a $2 \mathrm{~m}$ high, $7 \mathrm{~km}$ long internal ring berm (perimeter berm) was constructed upstream of the perimeter dyke between 2002 and 2004. Stacking tailings interior of the perimeter dyke has the benefit of maintaining stability of the perimeter drainage system and eliminating costly perimeter dam construction. To date, three lifts of berm have been completed providing over $25 \mathrm{Mt}$ of storage.

The perimeter berm was originally designed to have a $20 \mathrm{~m}$ buffer distance between subsequent lifts. As the rate of tailings accretion was found to be quite variable along the berm length, the design was subsequently modified to allow upstream stacking from the starter dam crest. This has allowed the construction to proceed on an as required basis providing maximum degree of flexibility to site operation. Guidelines for berm raising and modification of the drainage works have been prepared to aid field operators. Berm raising is under the direction of the design engineer.

The thickened tailings slurry is discharged at a number of locations along the South Bypass Road and the Main Line Berm. General guidance for deposition is provided in a bi-annual tailings deposition plan with routine oversight by the design engineer. Tailings deposition operation is to ensure that the entire active tailings area is covered by fresh tailings on a yearly basis to inhibit oxidation of the tailings. The tailings beach should maintain a positive drainage gradient along the upstream side of the perimeter berm towards the effluent collection ponds by discharging tailings in a counter-clockwise sequence. Experience has shown that deposition is best guided by field observation along the perimeter berm, as tailings build-up on the perimeter berm is typically irregular. Results of annual geochemistry monitoring as well as tailings beach survey also help to prioritise the deposition sequence.

\subsubsection{Perimeter discharge}

The Musselwhite thickener underflow is discharged along the discharge dyke to form a tailings beach sloping towards the separation dyke (Figure 2). The dyke is typically raised in $2 \mathrm{~m}$ lifts.

There are two $150 \mathrm{~mm}$ tailings lines: one on the north and the other one the south limb of the discharge dyke. The tailings slurry is end discharged onto the tailings beach on a trestle. The primary discharge points are spaced $30 \mathrm{~m}$ apart and are operated sequentially for duration of about two weeks at each location. Periodically, secondary deposition is carried out to infill the depressions between the primary discharge points. The spacing of the discharge points can vary according to the storage capacity available at a location. Between 2010 and 2013, dyke raising was performed annually and deposition was adjusted to maximise the available capacity. Tailings deposition cycles annually along the discharge dyke to ensure a 
uniform rise in the tailings beach. The deposition location is moved progressively closer to the thickener in freezing conditions to minimise the risk of clogging. The HDPE tailings lines are cut and spliced onsite.

\subsubsection{Cell deposition}

CDP requires construction of dykes on the deposited tailings. These dykes can be raised to match the overall filling rate. Dyke construction on wet ground is a challenge but can be managed with good geotechnical oversight. The rate of rise is typically fast in CDP making this method less conducive to tailings drying. At Neves Corvo, several cells are operated concurrently to maximise exposure and to allow consolidation of the underlying tailings. Intermittent deposition in cells is also a key element in the optimised seasonal deposition concept (Caldwell et al. 2014) by maximising atmospheric dewatering (air drying in summer and freezing in winter). This approach has been successfully used to treat the large volume of lime treatment sludge generated at the Kidd TMA each year.

Both perimeter discharge and central discharge can occur in a tailings cell. The former is more common as it simplifies water management and deposition. Water should not be allowed to pond in the deposition cell as it retards drying and can present stability problem if the cells are not built up at the same rate.

\subsubsection{Down-valley discharge}

The authors have no direct experience on DVD. With the deposition point elevated and located at considerable distance from the perimeter dam, it can be expected that the extents of beach are very much controlled by the topography and the yield stress of the tailings. In wet climate, the deposited tailings surface can suffer significant erosion due to concentration of surface runoff flowing down the valley. Large fluctuations of the tailings pond level can occur if the contributing watershed is large.

\subsection{Surveillance and monitoring}

\subsubsection{Thickener performance}

The thickening operations at all of the example tailings facilities are monitored closely. Kidd Metsite and Musselwhite maintain a continuous record of underflow slurry densities and other operating parameters. At Neves Corvo, the underflow yield stress is routinely monitored. The data provide feedback on the plant performance and allow changes to be made to optimise operation. For example, at Kidd Metsite the flocculent dosage is slightly increased in winter to compensate for a lower settling efficiency (Kam et al. 2009). On occasion, the thickener underflow density is also adjusted to facilitate deposition due to the length of the delivery line and head of discharge.

\subsubsection{Beach slope profile}

As part of tailings deposition planning, Kidd conducts annual beach slope surveys along a number transect lines. Figure 3 shows the beach profiles along one of these lines for the period from 2000 to 2013. It can be seen that the beach has an average slope of $2 \%$ and that the slope has improved with time due to better deposition practices. Similarly, the Musselwhite TMA is surveyed annually to monitor the beach profile at two locations. 


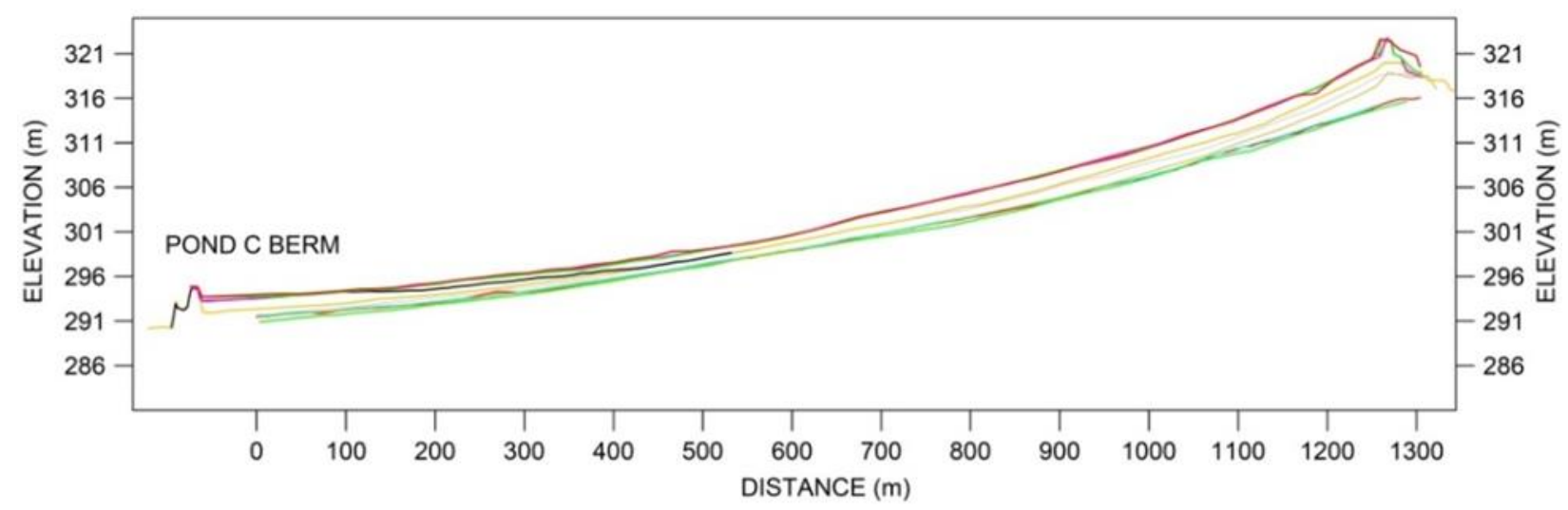

Figure 3 Kidd Metsite TMA beach profile - transect A, 2000-2013

\subsubsection{Tailings/pond survey}

Tailings topographic and bathymetric surveys are routinely carried out to support construction activities as well as to verify that there are adequate tailings and water storage capacity. This is particularly important for Musselwhite where the water pond is progressively infilled. The Kidd TMA ponds are regularly surveyed as part of the maintenance dredging program for tailings and sludge.

\subsubsection{Geochemistry survey}

One of the key objectives of deposition at the Kidd and Neves Corvo TMAs is to, on a yearly cycle, overlay the deposited tailings with fresh tailings so as to prevent the onset of oxidation. The effectiveness of deposition is verified from a geochemistry survey. At Kidd TMA, the tailings $\mathrm{pH}$ and conductivity are measured along a number of beach profiles annually.

\subsubsection{Geotechnical testing (field and laboratory)}

Laboratory and field testing of the deposited tailings have been performed periodically at all of the reference sites (Kam et al. 2009, 2014; Lopes et al. 2013). Tailings properties that are measured have included grain size distribution, specific gravity, deposited dry density, in situ shear strength, water content, void ratio, settling, consolidation and drying behaviour. One of the key performance indicators is the lack of sorting on the tailings beach.

\subsubsection{Special surveillance}

Snow melt runoff can be very difficult to handle in a large tailings area. This is most critical in a CD facility where there is limited water retention capability to moderate the inflow. At the Kidd TMA, drainage is conveyed to the perimeter ditch through a series of culverts on the perimeter berm. These culverts are closely inspected for ice blockage during the spring freshet. Extreme cold temperatures can also cause the perimeter ditch to freeze. Guidelines have been developed to step up surveillance for such an occurrence. A visual inspection is also carried out by an engineer each year to confirm the adequacy of the culverts and available freeboard on the perimeter berm.

\subsubsection{Deposition planning and review}

Tailings deposition reviews have been carried out biannually since 2002 to assess the performance of the Kidd TMA and to provide guidance for the tailings operation and construction. At Musselwhite and Neves Corvo, deposition modelling is undertaken regularly to control the stack raising volumes and to adjust the deposition strategies to optimise tailings distribution and effective use of space. 


\section{$4 \quad$ Water management}

Water management requirements are climate-dependent and can vary substantially for different tailings facility types. In arid regions where there is a net water, deficit surface runoff is collected for processing and excess water is commonly discharged to evaporation ponds. In contrast, in wet regions tailings effluent must be safely managed, treated if required, before recirculating to the mill or releasing to the environment. With a surface area of over 1,000 ha, Kidd treats on average about $60,000 \mathrm{~m}^{3}$ of effluent and discharge $33,000 \mathrm{~m}^{3}$ to the environment each day. The daily discharge can exceed $500,000 \mathrm{~m}^{3}$ at the peak of the spring freshet. Some of the operational issues that arise during the peak discharge periods can range from high erosion of tailings slope, infilling of the perimeter dykes and water ponds, to poor solids settling due to reduced retention times.

\subsection{Case studies}

\subsubsection{Central discharge}

The perimeter berms at the Kidd TMA are not water retaining. Drainage is provided by a series of culverts on the berm. Each of these culverts was sized to handle the runoff from a sector of the tailings cone as shown in Figure 1. At each culvert location, a cross berm is provided to intercept the flow from the up gradient area. This arrangement ensures that the culvert capacity is fully utilised up to the 100 year return runoff event. Larger storm flows are passed over the cross berm to the adjacent cell and eventually to the lowest culverts close to the collection pond. These culverts are capable of passing the 1,000 year flow. The pie shaped drainage design provides maximum flexibility for berm construction. Each of the drainage sectors can be raised independently to suit the rate of tailings build-up.

To maintain the flow capacity of the culvert a protective rockfill berm is placed upstream of the inlet. This berm is periodically raised to contain the tailings. Occasionally, due to uneven accumulation of tailings upstream of the perimeter berm, the tailings are excavated to restore drainage to the culvert. Erosion of tailings along the drainage ditches is an ongoing issue requiring the water collection ponds to be dredged. The dredged tailings are disposed of in cells constructed within the TMA.

\subsubsection{Perimeter discharge}

The Musselwhite tailings pond volume will continue to reduce as the tailings cell is gradually filled. In preparation for the spring runoff, the tailings pond is drawn down in the fall to maximise its storage capacity. A contingency raised storage cell has been proposed to increase flexibility to handle the peak inflow.

\subsubsection{Cell deposition}

CDP usually can result in temporary pooling of water at the downstream end of the cell. This is necessary for solids removal during deposition with drainage provided by spillways or overflow culverts. The deposition sequence should ensure that the cells are drained at all times.

\subsubsection{Down-valley discharge}

In a DVD facility, the deposited tailings could be susceptible to surface erosion. An internal berm may be considered to lower the suspended solids loading in the reclaim pond. Large fluctuations of the tailings pond level can occur if the contributing watershed is large. The perimeter dam is typically water retaining, and requires raising in the downstream direction.

\section{$5 \quad$ Contingency planning}

High-density disposal systems are more complex to operate than conventional slurry disposal. At the design stage, sensitivity analyses should be carried out to investigate design and construction implications over a range of plausible beach slopes. 
In wet climatic conditions, sufficient drying time should be included in the deposition sequence if construction us to occur over the deposited beach. The use of a geogrid can expedite construction on soft ground.

During an outage of the thickened tailings plant, low-density slurry tailings are discharged in the TMA resulting in a reduction in the tailings beach slope. Both Kidd and Musselwhite have dedicated disposal areas for unthickened tailings. On a short-term basis, the overall performed of the tailings is unaffected as the segregated tailings will eventually be encapsulated by thickened or paste tailings. However, in a CD facility, prolonged plant stoppage could lead to a rapid build-up of tailings along the perimeter structure and cause an excessive amount of tailings to migrate to the downstream water ponds.

Drainage is critically important for CD facilities in wet climate. At Kidd TMA, this surge capacity was provided by expanding the footprint of the water collection ponds.

\section{$6 \quad$ Closure considerations}

A closure dry cover is usually provided on the deposited tailings to ensure long-term physical and chemical stability of the tailings, reduce dusting impact and improve the site aesthetics. Cover types can range from a simple re-vegetation layer to a complex multi-layer engineered system that is designed to inhibit tailings oxidation. The choice of the cover type will depend on the climate, hydrogeological condition of the TMA and most importantly the availability of borrow material for construction. At Musselwhite, the phreatic surface is expected to remain close to the surface after closure except for the perimeter of the tailings stack which will be de-saturated to a substantial depth. The hydrogeological condition at Kidd is more complex. In the centre of the cone, the groundwater table is significantly depressed due to low infiltration and drawdown from the long perimeter. In the groundwater discharge zone around the TMA perimeter, the ground is saturated and can present a challenge for construction. Multiple cover types are expected to be deployed at both of these sites. Figure 4 illustrates a conceptual layout of the dry cover plan at the Musselwhite TMA. 


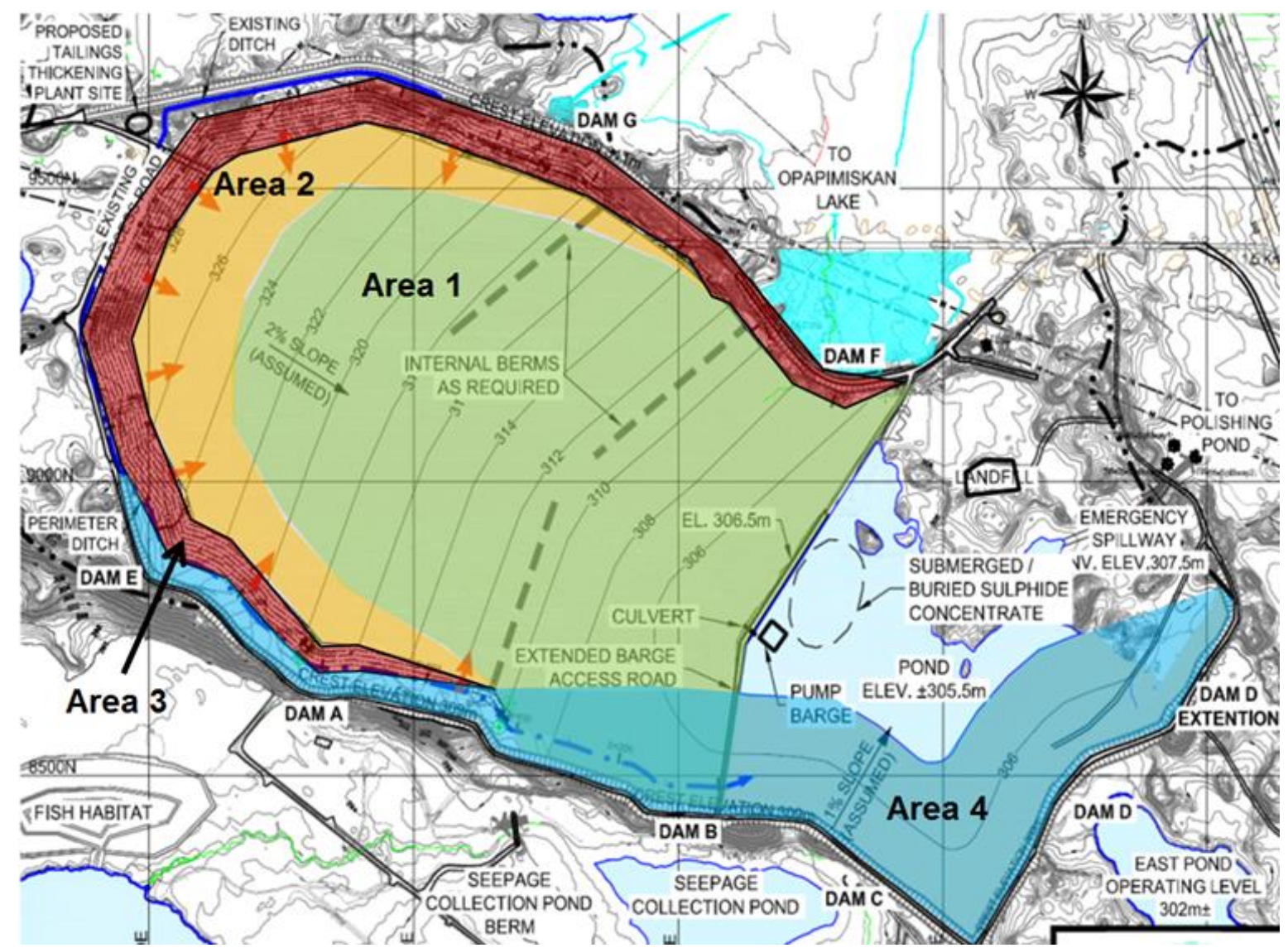

\section{Figure 4 Conceptual dry cover plan, Musselwhite TMA showing different cover types}

Given the high cost of construction and uncertainty associated with cover design, field trials have been initiated at both sites to assess the long term performance of the various cover designs. The field trials also demonstrated the constructability of the cover in wet ground conditions. Additional field data will be collected to better characterise the hydrogeological regime at both sites.

The Kidd TMA closure dry cover will be constructed with waste rock and clean tailings obtained from a nearby site. The cover downstream of the perimeter berm will be mechanically placed. Within the active tailings deposition area the clean tailings will be thickened and discharged from the centre of the TMA. The entire cover construction will require placement of $6.7 \mathrm{M} \mathrm{m}^{3}$ of fill over a three-year period. The Musselwhite cover will be constructed with till and sand and gravel. A network of drainage ditches will be provided to minimise potential for cover erosion.

\section{Conclusion}

The success or lack of success of any paste and thickened tailings disposal systems must be viewed in the context of expectations. With respect to beach slope which is a common measure for performance the 'design' slope should be realistic (best estimate based on all available information) and more importantly, taking into consideration variability that can be caused by operational and climatic factors. The TMA design has to be flexible to accommodate the range of beach slopes and such risk communicated to the owner. 
The disposal of low-density slurry during outage of a thickened or paste system can present a significant operational challenge. The TMA design should include an emergency storage for unthickened tailings. In freezing conditions, water can be lost in ice and the drainage works can be susceptible to freezing and ice jams.

Tailings deposition is best managed through an observational approach with the location and duration of discharge adjusted to suit field condition. The ability to direct tailings flow in a large CD TMA is limited. The tailings operation must be flexible to accommodate uneven tailings build-ups along the perimeter.

High-density tailings disposal in cold and wet climate requires careful planning and close monitoring. Field data should be collected to validate performance and the deposition plan updated based on site conditions. Clear guidance must be given to field staff to manage site drainage and the construction activities, particularly for the $C D$ tailings facilities.

Closure dry cover is a major cost. It is recommended that field trials be conducted to confirm and optimise the cover design. The hydrogeological condition in a high-density tailings disposal facility can be variable and will impact the closure dry cover design.

\section{References}

Caldwell, J, Revington, A, McPhail, G \& Charlebois, L 2014, 'Optimised seasonal deposition for successful management of treated mature fine tailings', in R Jewell, A Fourie, PS Wells \& D. van Zyl (eds), Proceedings of the 17th International Seminar on Paste and Thickened Tailings, Australian Centre for Geomechanics, Perth, pp. 371-379.

Cooper, RA \& Smith, ME 2011, 'Case study - operation of three paste disposal facilities', in RJ Jewell \& AB Fourie (eds), Proceedings of the $14^{\text {th }}$ International Seminar on Paste and Thickened Tailings, Australian Centre for Geomechanics, Perth, pp. 261-270.

Fitton, TG 2014, 'The accuracy of tailings beach slope predictions', in RJ Jewell, AB Fourie, PS Wells \& D van Zyl (eds), Proceedings of the 17th International Seminar on Paste and Thickened Tailings, Australian Centre for Geomechanics, Perth, pp. 47-58.

Habte, K, Merry, P, Welch, D \& Chouinard, L 2014, 'Design and performance of a water collection dam with permafrost seepage barrier, Nunavik Nickel Mine, Quebec', Proceedings of the Canadian Dam Association Annual Conference.

Kam, S, Hmidi, N \& Mao, Y 2014, 'Field performance of thickened tailings disposal at Musselwhite Mine', in RJ Jewell, AB Fourie, PS Wells \& D van Zyl (eds), Proceedings of the 17th International Seminar on Paste and Thickened Tailings, Australian Centre for Geomechanics, Perth, pp. 627-639.

Kam, S, Yaschyshyn, D, Scott, D \& Patterson, M 2009, 'Thickened tailings disposal at Xstrata Copper Kidd Metallurgical Site', Proceedings of the 8th International Conference on Acid Rock Drainage, American Society of Mining and Reclamation, Champaign.

Lopes, R, Bahia, R, Jefferies, M \& Oliveira, M 2013, 'Paste deposition over an existing subaqueous slurry deposit of high sulphide content tailings - the Neves Corvo experience', in RJ Jewell, AB Fourie, J Caldwell \& J Pimenta (eds), Proceedings of the 16th International Seminar on Paste and Thickened Tailings, Australian Centre for Geomechanics, Perth, pp. 21-35.

Raposo, N, Bahia, R, Afonso, E \& Topa Gommes, A 2014, 'Optimisation of thickened tailings deposition', in RJ Jewell, AB Fourie, $P$ Wells \& D van Zyl (eds), Proceedings of the 17th International Seminar on Paste and Thickened Tailings, Australian Centre for Geomechanics, Perth, p. 651.

Theron, M, Addis, P, Wates, J \& Vincent, M 2005, 'Buyanhulu Mine paste tailings facility, relating the unsaturated properties of gold tailings to rate of rise', in RJ Jewell \& S Barrera (eds), Proceedings of the 8th International Seminar on Paste and Thickened Tailings, Australian Centre for Geomechanics, Perth, pp. 219-230.

Wates, JA, Venter, H, O'Callaghan, A \& Tucker, J 2014, 'The influence of feed properties on cyclone performance and stacking of underflow', in RJ Jewell, AB Fourie, PS Wells \& D van Zyl (eds), Proceedings of the 17th International Seminar on Paste and Thickened Tailings, Australian Centre for Geomechanics, Perth, pp. 445-458.

Williams, MPA, Seddon, KD \& Fitton, TG 2008, 'Surface disposal of paste and thickened tailings - a brief history and current confronting issues', in AB Fourie, RJ Jewell, PT Slatter and A Paterson (eds), Proceedings of the 11th International Seminar on Paste and Thickened Tailings, Australian Centre for Geomechanics, Perth, pp. 143-164.

Yuan, XS \& Lahaie, R 2010, 'Paste and thickened tailings technology and its application in oil sand tailings management', in RJ Jewell \& AB Fourie (eds), Proceedings of the 13th International Seminar on Paste and Thickened Tailings, Australian Centre for Geomechanics, Perth, pp. 437-449. 
